\title{
An Investigation on How Teachers are Using Augmented Reality in Their Lessons
}

\author{
Manoela M. O. da Silva ${ }^{1}$, Iulian Radu' ${ }^{2}$, Bertrand Schneider ${ }^{2}$, \\ Patricia Smith Cavalcante $^{3}$, Veronica Teichrieb ${ }^{1}$ \\ ${ }^{1}$ Voxar Labs - Centro de Informática - Universidade Federal de Pernambuco (UFPE) \\ Recife - PE - Brazil \\ ${ }^{2}$ Harvard Graduate School of Education \\ Cambridge - MA - USA \\ ${ }^{3}$ Edumatec - Centro de Educação - Universidade Federal de Pernambuco (UFPE) \\ Recife - PE - Brazil \\ mmosecin.ufpe.br, iulian@gatech.edu \\ bertrand_schneider@g.harvard.edu, patricia3smith@gmail.com.br \\ vt@in.ufpe.br
}

\begin{abstract}
Educational possibilities using Augmented Reality (AR) have been increasingly recognized by researchers and practitioners. This work aims to characterize teachers who currently use AR and understand their needs, expectations and limitations. Seven teachers and two coordinators were interviewed to understand what tools they are using, as well as why and how they were used. Data have shown that this use is still limited. Content creation was even more limited. We observed the need for authoring tools that are more user-friendly and enable both teachers and students to create content independently, as well as to evaluate learning in more flexible ways.
\end{abstract}

Resumo. As possibilidades educacionais usando Realidade Aumentada (RA) têm sido cada vez mais reconhecidas pelos pesquisadores e profissionais. Este trabalho tem como objetivo caracterizar professores que atualmente usam RA $e$ entender suas necessidades, expectativas e limitações. Sete professores $e$ dois coordenadores foram entrevistados para entender quais ferramentas estão usando, bem como por que e como elas estão sendo usadas. Os dados mostraram que esse uso ainda é limitado. A criação de conteúdo foi ainda mais limitada. Observamos a necessidade de ferramentas de autoria que sejam mais fáceis de usar e que possibilitem professores e alunos criar conteúdo de maneira independente, bem como avaliar o aprendizado de maneiras mais flexíveis.

\section{Introduction}

Augmented Reality (AR) enables the combination of the real and virtual world in a coherent way. Its educational possibilities have been increasingly recognized by researchers who have been developing a variety of AR applications aimed at education. This technology has some affordances that may help to support learning, such as: its ability to 
VII Congresso Brasileiro de Informática na Educação (CBIE 2018)

Anais do XXIX Simpósio Brasileiro de Informática na Educação (SBIE 2018)

encourage kinesthetic learning and the possibility to see virtual content in a 3D perspective. The coexistence of virtual and real environments also allows learners to experience phenomena that otherwise would be impossible in the real world, interact with two- or three-dimensional synthetic objects in the mixed reality environment and develop important practices and literacies that cannot be developed in other learning environments [Wu et al. 2013].

AR educational experiences are different due a number of reasons including: support of seamless interaction between real and virtual environments, use of tangible interface metaphor and ability to transition smoothly between reality and virtuality [Billinghurst 2002]. Studies have shown that AR has a positive impact on student's motivation [Radu 2014]. AR can be used to leverage learning of contents from different areas. AR applications can aid varied age levels ranging from young children to university students [Cai et al. 2014, Redondo et al. 2013].

Despite these learning opportunities, AR use is still not widespread. One reason might be that we have few projects exploring AR for education. Time and technical expertise are two of the reasons that hinder the far-reaching use of authoring tools for educational AR-based projects [Roberto et al. 2016].

One popular app that explores AR creation is HP Reveal [HP Reveal 2018] formerly known as Aurasma Studio, which enables users to create auras for their AR experiences. Simpler and easier to use authoring tools would enable much more exploration from teachers and students. Other example that shows the numerous possibilities created by such authoring tools is the Scratch [MIT Media Lab 2007], a programming language developed by the MIT (Massachusetts Institute of Technology). Although there is still the need for programming, its simplicity has enabled its increasing use in schools. Other works have investigated this issue [Vert and Andone 2017], however, they usually base their decisions only on scientific literature. Thus, our main difference is that we investigate AR authoring tools for education using a design-based approach.

Our aim is to investigate teacher's use of AR to identify their needs for authoring. This paper presents the first step of this process, which is to characterize the teachers who currently use AR, their needs, expectations and limitations. Our contribution is to provide a better understanding of the users, which will be used as input for future design guidelines.

\section{Methodology}

As opposed to existing works on AR authoring tools which have focused mainly on the predictive approach, this work uses the design-based approach whose ultimate goal is to build a stronger connection between educational research and real-world problems [Amiel and Reeves 2008]. These authors explain that in traditional empirical predictive research, a new technique or device is tested in a controlled environment. The time of engagement with the 'stimulus' is usually limited and although iterations to refine hypotheses are encouraged, commitment to iterative design is also usually limited.

Design-based research, on the other hand, calls for iterative cycles of study that lead to a better understanding of the process of intervention (it is process-oriented). The choice for this approach is based on the nature of the problem we intend to tackle. As 
VII Congresso Brasileiro de Informática na Educação (CBIE 2018)

Anais do XXIX Simpósio Brasileiro de Informática na Educação (SBIE 2018)

pointed out by [Amiel and Reeves 2008], "integrating technologies into the classroom leads to substantial changes in social organization, student-teacher relationships, and a myriad of other factors that cannot be investigated successfully by predictive research."

The first stage of a design-based research consists in an "analysis of practical problems by researchers and practitioners in collaboration". Thus, our goal in this first stage of research is to characterize the teachers who currently use AR and understand what are their needs, expectations and limitations. To achieve that, seven teachers and two coordinators who have experience with AR were interviewed. The online semi-structured interviews were conducted from November, 2017 to March, 2018. The shortest one lasted $34 \mathrm{~m} 06 \mathrm{~s}$ and the longest one lasted $1 \mathrm{~h} 17 \mathrm{~m} 15 \mathrm{~s}$. Their average length were $49 \mathrm{~m} 13 \mathrm{~s}$.

Our research questions are: (a) What is the profile of the teachers who currently use AR?; (b) How is their planning process?; (c) What are teachers experiences with AR for education? and (d) What are teachers experiences with content creation for AR?

The interview protocol ${ }^{1}$ was created by one of the researchers and reviewed by two others. It covers three themes: (a) Teacher's background - questions aimed to characterize the user's educational background and experience; (b) Teacher's planning process and its impact in AR use - part aimed to understand teacher's planning and resource selection process; and (c) Use of AR - part aimed to characterize teachers experiences using AR.

Since it was difficult to find participants for this study, different recruitment techniques were employed. Participants were recruited from the Google Innovator community as well as from social media communities related to AR for education. Participants were also requested to indicate fellow teachers that qualify for the study.

\subsection{Data Analysis}

We carried out a qualitative approach to analyze the data. We followed the phases of thematic analysis [Braun and Clarke 2006] as displayed below. The analysis was conducted by one of the researchers and discussed with the other authors. The unit of analysis is all teachers' responses considered together.

1. Familiarize yourself with the data - the interviews were read and re-read. Initial notes were taken during this phase;

2. Generate initial codes - Interesting features of the data were collected from the entire dataset. Codes were generated;

3. Search for themes - Codes were collated into potential themes;

4. Reviewing themes - Themes were checked in relation to the coded extracts and the entire dataset, which generated a thematic map of the analysis;

5. Defining and naming themes - The specifics of each theme were refined to generate clear definitions and names for each theme;

6. Producing the report - A report of the analysis was produced.

\section{Results}

This section will present the results from the interviews.

\footnotetext{
${ }^{1}$ Available at https://goo.gl/SYVNF 8 .
} 
VII Congresso Brasileiro de Informática na Educação (CBIE 2018)

Anais do XXIX Simpósio Brasileiro de Informática na Educação (SBIE 2018)

\subsection{Participants' background}

Seven teachers and two coordinators who used AR were interviewed. They will be identified by $\mathrm{T}$ (teachers) or $\mathrm{C}$ (coordinators) and their corresponding numbers. They teach in a variety of scenarios and subjects. There are five females and four males. Apart from the coordinators, they teach nature and science ( 5 teachers), followed by languages, math and humanities (1 teacher each). T4 teaches both math and science. Overall, they had the following characteristics:

1. Have been teaching for 14.8 years (on average);

2. 37 years old (on average);

3. Have undergraduation and an additional specialization or master degree;

4. Brazilian. Other nationalities included are North American (1) and Swedish (1);

5. Work in elementary or high school;

\subsection{Teacher's planning process and its impact in AR use}

Through the analysis, we identified three types of planning process as detailed below.

1. Early planning - this means the teachers plan their lessons in advance;

2. Planning in action (adjustments during the lesson) - it refers to adjustments reported during the lessons;

3. Unplanned lesson - it reflects situations in which teachers do not plan in advance;

The same teacher can plan in different ways depending on the context. For instance, T1 stated that she has two types of planning the ideal (that happens in the beginning of the semesters) and the rushed one (that happens from the middle to the end of the semesters). For the ideal planning, she usually thinks about the goals in terms of behavior and ability. Later, she connects that with the content, selects materials to be used and, then, prepare the lesson. The rushed planning occurs due to the need to adjust planning to meet the institutions' demands, such as to fulfill the contents and test students.

\subsection{Use of $A R$}

This category intends to characterize teachers experiences using AR.

\subsubsection{AR Tools Used}

The most mentioned tools were the Aurasma (mentioned by $44.4 \%$ of the teachers), which is now called HP Reveal [HP Reveal 2018], Elements 4D [DAQRI 2013] (22.2\%) and Quiver [QuiverVision Ltd 2018] (22.2\%) as seen in Figure 1. Other tools mentioned (11.1\% each) were: (a) Pokémon Go [Niantic, Inc. 2016]; (b) Metaverse [GoMeta, Inc. 2018]; (c) 4D Mais [4Dmais 2018]; (d) The Cell [Galembeck 2017]; (e) Anatomy 4D [DAQRI 2014]; (f) Treasure Hunt App [Tavares et al. 2015]; (g) Lifeliqe [Lifeliqe Inc 2018] and (h) Google Expedition with AR [Google Inc 2018].

\subsubsection{Rationale for AR Use}

Three main reasons were identified as a justification for AR use: (a) Improvement in students' learning; (b) Positive initial teacher evaluation and (c) Continuing education. Each of these reasons were subdivided as detailed in Figure 2. 
VII Congresso Brasileiro de Informática na Educação (CBIE 2018)

Anais do XXIX Simpósio Brasileiro de Informática na Educação (SBIE 2018)

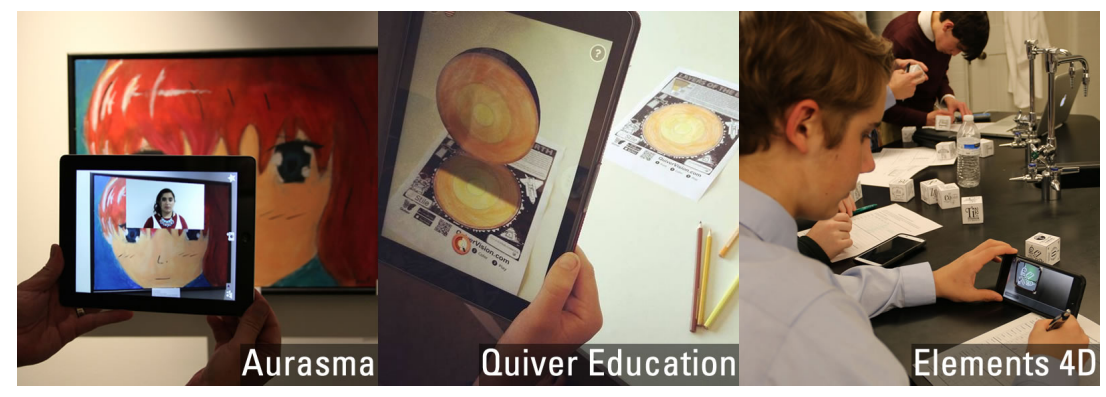

Figure 1. Mostly Used AR Tools.

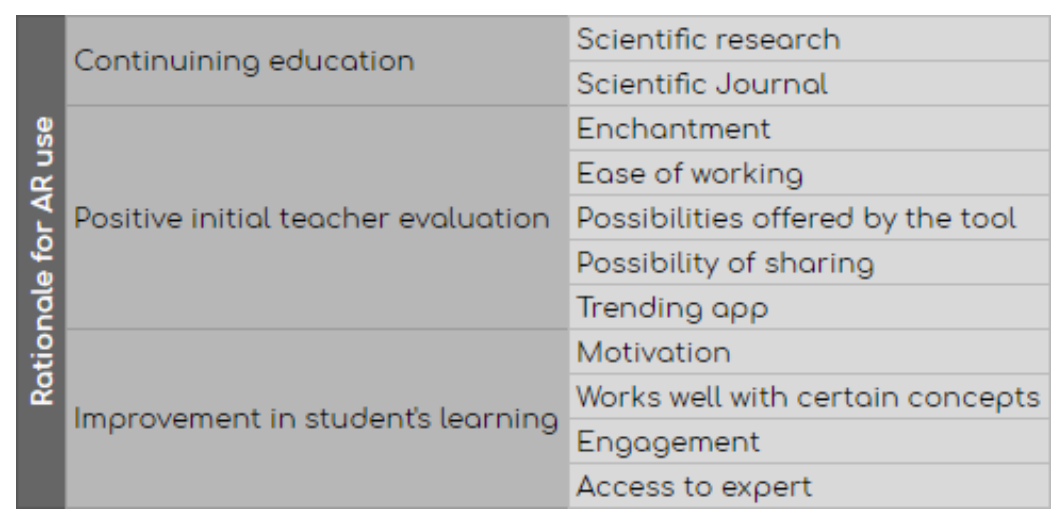

Figure 2. Rationale for AR Use.

Two teachers based their decision in scientific research. T1 discovered AR tools during her master course. T4 is researching about the topic and learning to develop apps in that format. T5 mentioned scientific findings showing that: "students have longer retention and they also show better understanding when they get to work with something."2

Another reason for using AR is a positive teacher's initial evaluation. For instance, T7 thought the Anatomy 3D was a great application. "I found it awesome when I saw that body floating in front of me and I wanted to use it to learn that way because it is different." Two teachers found the Aurasma easy o use. T1 mentioned that it allowed her to work without programming knowledge while $\mathrm{C} 8$ highlighted its user-friendliness.

C9 mentioned that in her experience "Specialist teachers will seek according to the resource." In other words, they will chose the resources based on the its possibilities. T6 chose to use Pokémon Go because it was a trending app.

Another justification is through improvement in student's learning, which was evidenced in different ways, such as improvement in motivation and engagement. Some teachers mentioned that AR worked well to teach certain concepts, specially, abstract ones. T7 highlights the possibility to "draw a map of the body in your head."

\footnotetext{
${ }^{2}$ All teachers quotes are free translations made by the first author.
} 
VII Congresso Brasileiro de Informática na Educação (CBIE 2018)

Anais do XXIX Simpósio Brasileiro de Informática na Educação (SBIE 2018)

\subsubsection{Strategies for AR Use}

The strategies for AR use were divided into five categories: (a) AR content; (b) Learning objectives; (c) Infrastructure conditions; (d) Support Network and (e) Demand for resource use. Each of these categories and its subdivisions are illustrated in Figure 3.

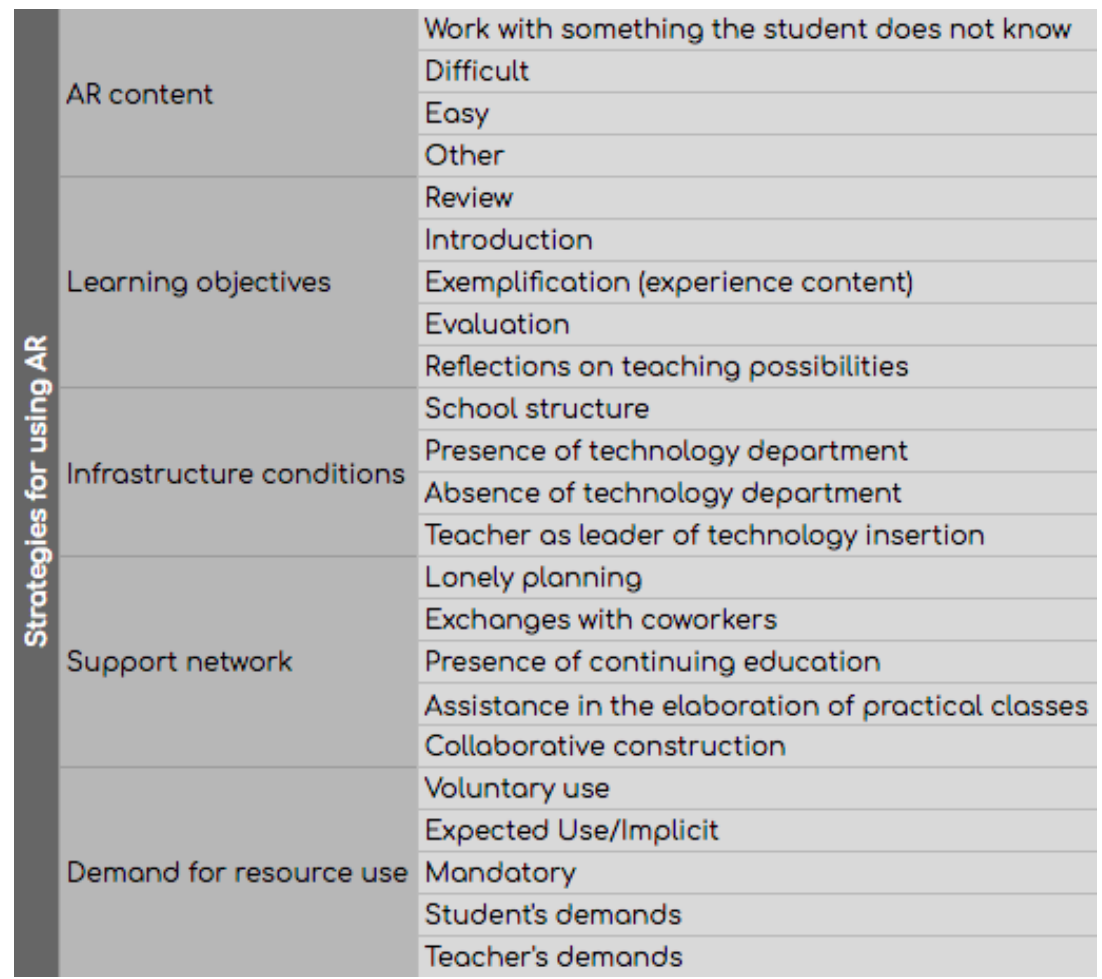

Figure 3. Strategies for AR Use.

Five participants worked with contents they considered easy. Whereas, six participants used it to work with contents considered difficult. T3, on the other hand, chose AR because this is something that his students have never been exposed to. Four participants worked with other types of content. Examples of this are the coordinators who presented AR to teachers to encourage its use. C8 had the role to "make the use of AR tangible." Likewise, C9 plays a role in "contextualizing the tool to the teacher."

AR was used to review, evaluate and exemplify contents. T5 argues that the Elements 4D can "illustrate chemistry through augmented reality." Three participants used AR to reflect on teaching possibilities. Only T2 used it to introduce new content.

School infrastructure varied a lot. Only T1 had access only to projectors. The other teachers, in general, have access to a variety of resources from the basics (computers, projectors and WI-FI) to the more sophisticated such as VR headsets and digital boards. Five teachers have a technology department in their workplaces, while three participants do not. T2 is currently moving from the position of teacher to technology manager. Two other teachers also took the leadership role in their institutions.

The most common form of planning is solitary. Although many teachers plan primarily alone, they have access to exchanges with coworkers, to continuous training or assistance for practical activities. C8 and C9 plan collaboratively. 
VII Congresso Brasileiro de Informática na Educação (CBIE 2018)

Anais do XXIX Simpósio Brasileiro de Informática na Educação (SBIE 2018)

Six types of demands for resource use (not necessarily AR) were found. Four teachers are expected to use technology as T4 explains: "I think anytime a device is put in the classrooms you know they expect the use of it." For the Swedish teacher, technology use is mandatory. Three teachers use it voluntarily. Two participants reported demands from the students. C9 stated that nowadays teachers are also demanding technology.

\subsubsection{Evaluation of AR Use in the Lessons}

The evaluation of AR use is subdivided in (a) Planning effectiveness, (b) Student's learning and (c) Future uses of AR as illustrated in Figure 4. Seven participants achieved complete effectiveness in their lessons. Two teachers underutilized it as T1 claims: "I did not use it in its potentiality." T1 claimed students had difficulties using both AR tools, Aurasma and The Treasure app. Two teachers stated that the types of questions proposed in the apps promoted low pedagogical gains. T1 argued that "Pedagogically speaking I think the gain of a treasure hunt with multiple choice question is minimal." Similarly, T3 claimed that the app The Cell presents very mechanical questions that do not encourage students to think. T3 discussed the effects of AR initial positive impact on his students. T7 also mentioned it and explained that too much emotion can disturb students' focus. T3 encouraged his graduate students to think about AR teaching possibilities. He mentioned that students reflected on the limitations of the tools. Although their first impression was very positive, when requested to think about an activity they started to see its limitations. T4 and C9 observed changes in student's interest in the content and in learning more.

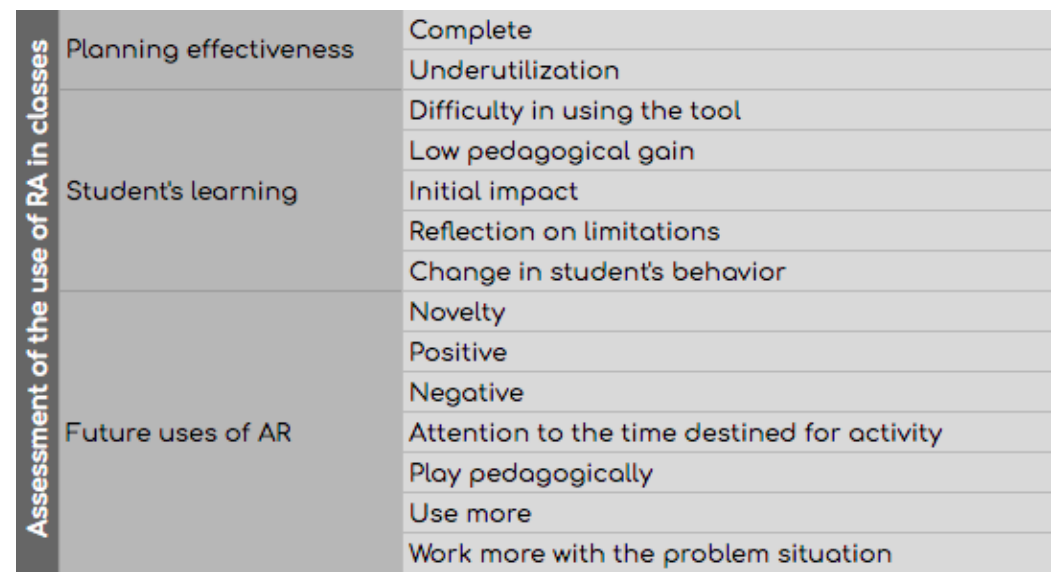

Figure 4. Evaluation of AR Use in the Lessons.

We observed aspects that could impact future AR uses as well as what could be maintained and improved in their experiences. The novelty effect was a controversial issue. While T1 considered it a "poor factor" as novelty is not novelty for long, T7 brings the neuroscience into perspective: "from the moment you use this tool, to the student it is a new tool. When you have a novelty in learning, this releases a series of substances in the brain that strengthen the formation of that memory so it is not a matter of being fun."

Different positive aspects were raised by teachers, such as: (a) Evaluating students previously, and (b) Enabling students to visualize abstract concept, among others. Two teachers mentioned explicitly they would like to use it more while others implied that. 
VII Congresso Brasileiro de Informática na Educação (CBIE 2018)

Anais do XXIX Simpósio Brasileiro de Informática na Educação (SBIE 2018)

Among negatives aspects were: (a) Diverse bugs, (b) Possibility of losing lesson's focus, and (c) Costs. Due to limitations of the tool, T3's students intended to use the Elements 4D to "play pedagogically". In other words, to demonstrate something to students and to grab their attention to chemistry. T2 and T7 revealed changes for next lessons, as: pay more attention to the activity time and work more with a problem situation.

\subsubsection{AR authorship}

The AR authorship process is shown in Figure 5. Only four participants (T1, T2, T4, C8) created something using AR. The content creator was the students ( 2 cases) and the teacher or coordinator ( 2 cases). All of them used Aurasma. Two teachers used it for evaluation purposes, one for content introduction and the coordinator to reflect about teaching possibilities. In her work place, teachers were provided with institutional support.

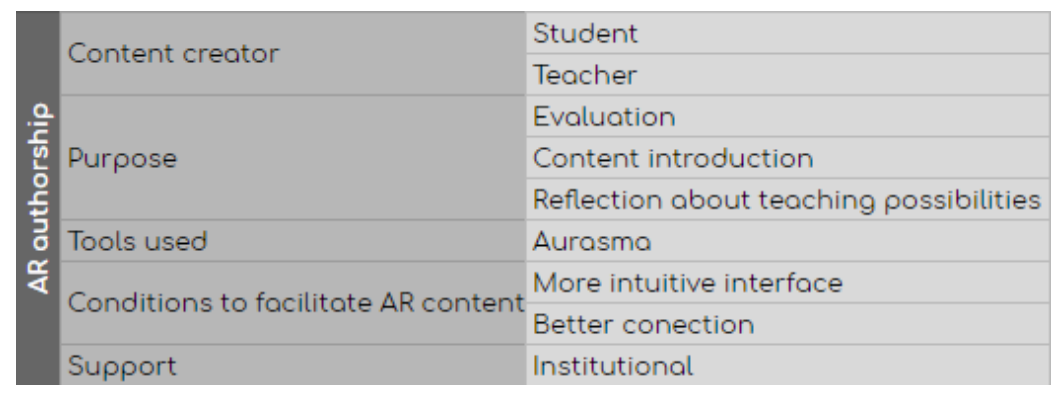

Figure 5. AR Authorship.

The contents worked in these experiences were: (a) The sugar economy, Brazilian History and First World War; (b) Future tense; (c) Solar system, digestive system and math problems and (d) Make AR use tangible. The creation process varied from teacher to teacher. T2 reported that students created contents in pairs. T2 mentioned that she created content by herself. C8 created an experience for the teachers. T4 requested students to create something that represented their learning. The Conditions to facilitate AR authorship refers to what participants reported as difficulties in the process. These conditions were: a more intuitive interface (3 mentions) as T4 explains "with the aurasma there is that challenge of sometimes it is quirky and it is difficult to use." and better connection.

\section{Discussion}

This section will discuss the most salient lessons learned regarding the themes.

\subsection{Teacher's background}

The data reveal that the teachers who used AR are usually well-experienced and mature. All of them have additional studies, either specialization or master degree. They also teach mostly nature and sciences, which might be due to what C9 noticed in her experience. She observed that most of the AR tools are related to this area.

\subsection{Teacher's planning process and its impact in AR use}

As mentioned above, three types of planning process were identified though the data: early planning, planning in action and unplanned lessons. The same teacher usually does 
VII Congresso Brasileiro de Informática na Educação (CBIE 2018)

Anais do XXIX Simpósio Brasileiro de Informática na Educação (SBIE 2018)

more than one type depending on the context. This is an important issue to consider when adopting new technologies such as AR since this process will require planning time from the teachers and possible planning in action since adjustments will probably need to be made on the go, impacting on classroom management and student's evaluation. An example is when T7 mentioned that emotion may hinder student's focus initially.

\subsection{Use of $A R$}

Data have shown that teachers who used AR usually have access to different technologies in their workplace. Also, they usually have a positive initial evaluation of the tool before using it with their learners. They revealed to have plenty of support either academic or in the workplace. However, some can be considered pioneers of this use. Although three participants were responsible for sharing AR use with other professionals or training teacher, the majority of uses occurred in regular schools. Although we understand that the majority of the teachers effectively achieved their objectives, AR use was still something specific for particular situations. Data have evidenced that for teachers to incorporate it more often there must be a way for them to customize the contents and types of activities proposed. Authorship was pretty limited as only four participants were able to achieve it and through the same tool, Aurasma. It was evidenced the need for more intuitive interfaces and also better infrastructure. Authorship can be done by teachers and students.

\section{Conclusion}

Data have shown that although AR technology is evolving, it's use is still limited specially in our Brazilian context. Nevertheless, there are teachers willing to learn and use AR in their classrooms due to its potential, specially for contents that are difficult to visualize or contextualize in other ways. These teachers usually had ample access to technology in the workplace and were provided with support, which might not be true for the overall teacher population. Thus, we can infer that AR is still something new for them and it might take some time until it is widespread in education.

Content creation was even more limited. Among the reasons for this, we believe are: lack of the teachers' experience with AR and lack of authoring tools. The data have shown that they only experienced content authoring with Aurasma and 3 out of the 4 participants mentioned that it was not so user-friendly. Our contribution is to raise awareness of teacher's needs when it comes to this technology and point out the need for more user friendly AR authoring tools, preferably based on teacher's previous knowledge. This would enable them to create content independently, decide appropriate ways to evaluate students' knowledge (it has been pointed out that multiple choice and conceptual questions are not the best ways to do it) and also enable students to demonstrate their learning (which was highly valuable to them). The need for user friendliness and attention to creation time is also evident if we consider that a recurrent complaint is lack of time.

As limitations, the teachers who used AR are in a way pioneers in the use of technology and may not represent the general population. As future works, we intend to extract guidelines for an AR authoring tool prototype considering teacher's needs.

\section{Acknowledgements}

We would like to thank the participants and Fundação de Amparo a Ciência e Tecnologia de Pernambuco (FACEPE) (processes IBPG-0605-1.03/15) for their funding. 
VII Congresso Brasileiro de Informática na Educação (CBIE 2018)

Anais do XXIX Simpósio Brasileiro de Informática na Educação (SBIE 2018)

\section{References}

4Dmais (2018). :::4Dmais:::. goo.gl/Rr4Lem. Accessed: 2018-04-29.

Amiel, T. and Reeves, T. C. (2008). Design-based research and educational technology: Rethinking technology and the research agenda. Educational Technology \& Society, 11(4):29-40.

Billinghurst, M. (2002). Augmented reality in education. https://goo.gl/sysbfB. Accessed: 2018-06-13.

Braun, V. and Clarke, V. (2006). Using thematic analysis in psychology. Qualitative Research in Psychology, 3(2):77-101.

Cai, S., Wang, X., and Chiang, F.-K. (2014). A case study of augmented reality simulation system application in a chemistry course. Computers in Human Behavior, 37:31 - 40.

DAQRI (2013). Elements 4D. goo.gl / 1 Ay 4kT. Accessed: 2018-04-29.

DAQRI (2014). Anatomy 4D. goo.gl / P jGYbv. Accessed: 2018-04-29.

Galembeck, E. (2017). The Cell. goo . gl / J81A6k. Accessed: 2018-04-29.

GoMeta, Inc. (2018). Metaverse. goo.gl/eEutaA. Accessed: 2018-04-29.

Google Inc (2018). Google Expeditions. goo . gl/V69vaz. Accessed: 2018-06-13.

HP Reveal (2018). HP Reveal - HP Reveal. goo . gl / BuwXWb. Accessed: 2018-04-29.

Lifeliqe Inc (2018). Lifeliqe. goo.gl/ iKUUEc. Accessed: 2018-04-29.

MIT Media Lab (2007). Scratch. goo . gl /WF zhp9. Accessed: 2018-05-01.

Niantic, Inc. (2016). Pokémon Go. goo . gl / jHkXdR. Accessed: 2018-04-29.

QuiverVision Ltd (2018). QuiverVision 3D Augmented Reality coloring apps. goo .gl/ v6Zi 6C. Accessed: 2018-04-29.

Radu, I. (2014). Augmented reality in education: a meta-review and cross-media analysis. Personal and Ubiquitous Computing, 18(6):1533-1543.

Redondo, E., Fonseca, D., Sánchez, A., and Navarro, I. (2013). New strategies using handheld augmented reality and mobile learning-teaching methodologies, in architecture and building engineering degrees. Procedia Computer Science, 25:52 - 61 .

Roberto, R. A., Lima, J. P., Mota, R. C., and Teichrieb, V. (2016). Authoring tools for augmented reality: An analysis and classification of content design tools. Design, User Experience, and Usability at HCII, pages 237-248.

Tavares, H., Lima, J. P., and Carvalho, Y. (2015). Jogo educacional de caça ao tesouro baseado em realidade aumentada treasure hunt educational game based on augmented reality. pages $92-97$.

Vert, S. and Andone, D. (2017). Zero-programming augmented reality authoring tools for educators: Status and recommendations. In 2017 IEEE 17th International Conference on Advanced Learning Technologies (ICALT), pages 496-498.

Wu, H.-K., Lee, S. W.-Y., Chang, H.-Y., and Liang, J.-C. (2013). Current status, opportunities and challenges of augmented reality in education. Computers \& Education, $62: 41-49$. 